\title{
AJARAN WUJUDIYAH MENURUT NURUDDIN AR-RANIRI
}

\author{
Rusdiyanto \\ Institut Agama Islam Negeri Manado, Sulawesi Utara, Indonesia \\ roesdysh@gmail.com \\ Musafar \\ Institut Agama Islam Negeri Manado, Sulawesi Utara, Indonesia \\ musafar.musafar@iain-manado.ac.id
}

\begin{abstract}
In the $16^{\text {th }}$ and $17^{\text {th }}$ centuries, the influence and power of Aceh Kingdom reached the sumatra Island and Malay peninsula. Also at that time, Aceh kingdom has acheived a lot of progress in the field of education, the development of thought aprreciation of islmaic teaching. Nuruddin Ar-Raniri is one of immigrant moeslim scholar who take part in the development of Islam in Aceh. His big agenda is to straighten agenda out the understanding of Islam which was brought first by his predecessors, they are Hamzah Fansuri and Syamsuddin as-Samatrani. Their Islamic teaching known by wujudiyah, its close with Ibn Arabi's mystical understanding or wahdatul wujud. According to ar-Raniri, there are three reasons to oppose this teaching. First, wujudiyah is identic with pre-Islmaic belief such as Christianity, Majusi and Brahmani. Second, Wujudiyah same with splinter sects in Islam that emerged after Prophed died, like Mu'tazilah dan Qadariyyah. Third, wujudiyyah is practices of deviant tarekat from Sunni. His opposition was caused basically he was a Sunni scholars who adheres wahdatus Syuhud's view. While in fiqh, he is an Asy'ariyah follower. His noncompromise actions against the wujudiyah followers were related to his life in India, which was filled with long intolerant conflicts between Hindus and Muslims.
\end{abstract}

Keywords : Nuruddin Ar-Raniri, Wujudiyyah, Sufism

Abstrak. Pada abad ke 16 dan 17 M, pengaruh dan kekuasaan kerjaan Aceh telah sangat terasa di kepulauan Sumatera dan Semenanjung Tanah Melayu. Dalam rentan waktu ini pula, kerajaan Aceh telah mencapai banyak kemajuan, terutama dalam bidang pendidikan, perkembangan pemikiran serta penghayatan terhadap ajaran Islam. Nuruddin Ar-Raniri merupakan salah satu ulama' pendatang yang ikut mewarnai perkembangan Islam di Aceh. Agenda besarnya adalah meluruskan pemahaman Islam yang terlebih dahulu disebarkan oleh Hamzah Fansuri dan Syamsuddin as-Samatrani. Ajaran yang dikenal dengan nama wujudiyah ini dekat dengan pemikiran sufistik ibn Arabi atau wahdatul wujud. Menurut arRaniri, terdapat tiga alasan mengapa ajaran tersebut perlu ditentang. Pertama Wujudiyah identik dengan agama dan kepercayaan pra Islam seperti Nasrani, Majusi dan Brahmaniyah. Kedua, ajaran Wujudiyah sama dengan ajaran sekte-sekte sempalan dalam Islam pasca Rasulullah wafat, seperti Mu'tazilah dan Qadariyyah. Ketiga, Wujudiyyah merupakan pengamalan dari tarekat yang sesat dan menyimpang dari konsep Islam Sunni. Penentangan ini disebabkan karena pada dasarnya ia adalah ulama' sunni yang menganut paham Wahdatus Syuhud dalam konsep tasawufnya. Sementara dalam bidang keilmuan lainnya, seperti fikih jelas sekali bahwa ia merupakan Ulama' sunni yang setia terhadap ajaran Asy'ariyah.Sikap non komprominya kepada terhadap para pengikut wujudiyah dikaitkan dengan kehidupan masa lalunya di India yang hidup dalam konflik berkepanjangan antara Hindu dan Islam yang tidak toleran.

Kata Kunci: Nuruddin Ar-Raniri, Wujudiyyah, Tasawuf 


\section{PENDAHULUAN}

Relasi hisotris Islam di Nusantara dan perkembangan Islam di Timur Tengah bisa dilacak sejak masa-masa awal kedatangan dan penyebaran Islam di Nusantara. Proses ini terjadi dalam kurun waktu yang panjang. Yaitu sejak terjadinya interaksi kaum muslim Timur Tengah dengan orang-orang Nusantara. Perlu diketahui bahwa terdapat beberapa perubahan dalam pola interaksi diantara mereka, yaitu berawal dari hubungan ekonomi dan perdagangan, kemudian disusul hubungan politik keagamaan, dan selanjutnya adalah hubungan intelektual keagamaan ${ }^{1}$. Sejumlah peneliti menyimpulkan bahwa asal muasal Islam di Nusantara dibawa oleh orang-orang muslim yang berasal dari Gujarat dan Malabar (India). Snouck Hurgronje menyebutkan bahwa abad ke 12 adalah masa yang paling memungkinkan terjadinya permulaan penyebaran Islam di Nusantara².

Dalam hal ini, Aceh adalah daerah awal tempat penyebaran Islam di Nusantara, mengingat bahwa selat Malaka yang dekat dengan Sumatra adalah jalur yang sering digunakan oleh orang-orang Gujarat tersebut untuk berdagang di Nusantara. Maka tidak heran jika kerajaan Islam pertama di Nusantara terletak di Sumatra. Ajaran Islam ini tentu saja dibawa oleh guru-guru pengembara yang juga banyak menghasilkan karyakarya tertulis - dengan karakteristik sufi yang kental ${ }^{3}$. Pada abad ke 16 dan $17 \mathrm{M}$, pengaruh dan kekuasaan daerah Aceh telah sangat terasa di kepulauan Sumatera dan Semenanjung Tanah Melayu,

\footnotetext{
${ }^{1}$ Azyumardi Azra, Jaringan Ulama Timur Tengah dan kepulauan Nusantara Abad XVII \& XVIII, (Jakarta: Kencana, 2007), h. 1.

2 Azyumardi Azra, Jaringan Ulama Timur..., h. 3.

${ }^{3}$ Oman Fathurrahman, Menyoal Wahdatul Wujud: kasus Abdurrahman Singkel di Aceh Abad 17, (Jakarta: Mizan, 1999), h. 20.
}

terutama pada masa pemerintahan Sultan Iskandar Muda (1636). ${ }^{4}$

Pada zaman tersebut, kerajaan Aceh telah mencapai banyak kemajuan, terutama dalam bidang pendidikan dan perkembangan pemikiran serta penghayatan terhadap ajaran agama Islam. Berkisar antara dua abad tersebut, telah muncul empat tokoh Ulama' yang sangat berpengaruh di daerah tersebut. Mereka adalah Hamzah Fansuri, Syamsuddin as-Sumatrani (1630), Nuruddin Ar-Raniri (1658) dan Abdurrauf as-Singkili (1693). Dua orang pertama adalah tokoh yang berpengaruh dalam penyebaran dan perkembangan mistik Ibn 'Arabi di daerah tersebut, dalam masa pemerintahan Sultan Iskandar Muda. Sedangkan dua tokoh terakhir mempunyai pemikiran yang berlawanan dari dua tokoh pertama. Nuruddin Arraniri yang datang lebih belakangan mempunyai pendapat bahwa ajaran yang di anut oleh muslim Aceh pada saat itu merupakan ajaran yang sesat, dan oleh karenanya perlu dibenarkan. Berpijak dari tesis ini, maka agenda dari Nuruddin ar-Raniri di Aceh adalah untuk membasmi ajaran wujudiyah dan menngantinya dengan ajaran-ajaran yang diyakininya benar.

Nuruddin Ar Raniri sendiri adalah seorang Ulama' dari India yang mempunyai pengaruh besar di Nusantara pada sekitar abad 17. Kedudukannya sebagai seorang penasehat Raja sekaligus mufti, jelas sangat memungkinkan untuk menyebarkan pemikiran-pemikirannya pada rakyat Aceh saat itu. Beberapa peneliti menyebut Ar-raniri sebagai tokoh sufi dan pembaharu paling penting pada abad ke 17.5

\footnotetext{
${ }^{4}$ Ahmad Daudi, Syeikh Nuruddin ArRaniri : Sejarah, Karya dan Sanggahan Terhadap Wujudiyah di Aceh, (Jakarta: Bulan Bintang, 1979), h. 7.

${ }^{5}$ Azyumardi Azra, Jaringan Ulama Timur...,h. 202.
} 


\section{Riwayat Hidup Nuruddin Ar-Raniri}

Nuruddin Muhammad bin Ali bin Hasanji al-Hamid (al-Humayd) al-Syafi'I al-Aydarusi al-Raniri, lahir di Ranir (sekarang Rander), sebuah kota pelabuhan tua di Gujarat. Lepas dari kota kelahirannya, ar- Raniri dianggap sebagai 'alim Melayu-Indonesia daripada India atau Arab. Tahun kelahirannya tidak diketahui, tapi kemungkinan ia lahir pada akhir abad ke 16. Ia belajar agama pertama kalinya di kota kelahirannya, kemudian ke Tarim (Arab Selatan) yang dipandang sebagai pusat studi ilmu agama pada masa itu. Kemudian ia melanjutkan ke Makkah dan Madinah untuk ibadah Haji (1621). Setelah itu, ia pulang ke India. Nuruddin adalah seorang Syaikh dalam tarekat Rifa'iyah. Ia diterima di tarekat ini melalui seorang guru tarekat, yaitu syaikh Abu Hafs Umar bin Abdullah Ba Syiban dari Tarim.

Asal kedatangan Nuruddin Arraniri tidak terlepas dari kemasyhuran Aceh sebagai kota pusat perdangangan yng menggantikan Malaka,karena pada saat itu, Malaka telah dikuasai oleh Portugis. Karena factor tersebut, dalam waktu 50 tahun, kota Aceh telah menjadi pusat perdagangan, kebudayaan, politik dan pengajian agama di kawasan Asia tenggara. Maka, tidak heran jika banyak orang dari berbagai Negara yang kemudian singgah di daerah ini. Dalam kitab Bustanus Salatin, Ar-Raniri mengatakan bahwa pamannya telah datang ke Aceh untuk mengajarkan beberapa Ilmu agama. Dari pamannya inilah, ia kemudian mengikuti jejaknya untuk merantau ke Aceh.

Kedatangannya ke Aceh untuk pertama kalinya, yaitu sebelum 1637 namun karena tidak mendapatkan sambutan yang layak oleh Sultan Iskandar Muda, ia kemudian melanjutkan perjalanan ke Semenanjung tanah Melayu dan menetap di Pahang. 6 Sebagaimana yang diketahi, bahwa pada masa pemerintahan Sultan Iskandar Muda, paham keagamaan yang di anut adalah Wujudiyah dengan tokohnya Syamsuddin as-Samatrani, yang dengan sendirinya paham tersebut bertentangan dengan ajaran yang dibawa oleh Ar-Raniri.

Puncak karier dari Nuruddin Arraniri sendiri dimulai pada kedatangannya yang kedua di Aceh, setelah meninggalnya Sultan Iskandar Muda yang digantikan oleh Sultan Iskandar Tsani, diikuti oleh kematian Syamsuddin As-Saamatrani (murid dari Hamzah Fansuri) sebagai tokoh agama. Ar-Raniri kemudian diangkat oleh Sultan Iskandar Tsani menjadi penasehat sekaligus Mufti dan mempunyai gelar Syaikh al-Islam pada masa pemerintahannya. Ar-raniri hidup selama tujuh tahun di Aceh. Dia banyak mencurahkan perhatian dan pemikirannya untuk menentang doktrin wujudiyah (ajaran dari Hamzah Fansuri dan Syamsuddin As-samatrani). Lebih jauh, dia bahkan mengeluarkan fatwa untuk memburu orang-orang sesat (pengikut paham wujudiyah), membunuh mereka yang tidak mau meninggalkan ajaran tersebut, juga membakar kitabkitab karya Hamzah Fanshuri dan Syamsudin as-Samatrani.

Dalam beberapa penelitian, dikatakan bahwa pembunuhan kaum wujudiyah ini berkaitan dengan kegiatan kelompok lain yang mengarah pada perebutan kekuasaan. Karena itu, Sultan Iskandar Tsani bertindak keras dan mendukung_ atau mungkin memerintahkan_ Nuruddin ar-raniri untuk mengeluarkan fatwa pembunuhan tersebut. Ar-Raniri berhasil

${ }^{6}$ Edwar Djamaris, Hamzah Fansuri dan Nuruddi Ar-Raniri, (Jakarta: Proyek Pengembangan Media Kebudayaan Direktorat Jenderal Kebudayaan Departement Pendidikan Dan Kebudayaan, 1995), h. 42. 
mempertahankan kedudukannya di Aceh sampai pada tahun 1644 ketika secara tiba-tiba ia memutuskan untuk kembali ke Raniri ${ }^{7}$. Hal ini ditulis oleh muridnya dalam kitab Jawahir al-Ulum. Diduga bahwa kepergiannya ada hubungannya dengan tindakan-tindakan Sultanah Safiatuddin, seorang permaisuri sekaligus pengganti dari Sultan Iskandar Tsani. Hal ini berkaitan dengan kepemimpinan seorang perempuan, baik di Aceh dan dalam hukum Islam merupakan sesuatu yang baru, bahkan tidak dibenarkan.

\section{Karya-Karya Nuruddin Ar-Raniri}

Ar-raniri adalah penulis produktif dan terpelajar. Menurut berbagai sumber, ia menulis tidak kurang dari 29 karya. Karya-karyanya banyak membicarakan tentang tasawuf, fikih, hadis, sejarah dan perbandingan agama. Beberapa karya ArRaniri yang terkenal ${ }^{8}$ adalah Bustan asSalatin, al Fath al Mubin, Rahiq alMuhammadiyah fi Thariq al-Shufiyah, Shirat al-Mustaqim, Durr al-Faraidl biSyarh al aqaid, Hidayat al-Habib fi alTarghib wa al-Tarhib, Nubdzah fi Da'wa al-Dzil Ma'a Shahibihi, Lathaif al-Asrar, Asrar al-lisan fi Ma'rifat al-Ruh wa alRahma, dan lainnya.

\section{Pemikiran Nuruddin Ar-Raniri}

Meskipun dikenal sebagia Ulama' yang menguasai berbagai bidang ilmu keagamaan, tetapi kebanyakan karya Nuruddin Ar-Raniri adalah dalam bidang tasawuf. Hal ini tidak bisa dilepaskan dari pola kehidupan masyarakat Aceh pada periode masa sebelumnya. Dimana pada masa kepemimpinan Sultan Iskandar Muda, masyarakat Aceh berada dalam masa Islam mistik, penganut doktrin wujudiyah dari Hamzah Fansuri dan Syamsuddin As-Samatrani.

${ }^{7}$ Azyumardi Azra, Jaringan Ulama Timur..., h. 212. lihat juga Oman Faturrahman, Menyoal Wahdatul Wujud..., h. 37.

${ }^{8}$ Ali Muhammad Abdillah, Tasawuf Kontemporer Nusantara, (Jakarta: Ina Publikatama 2011), h.16.
Terdapat aspek-aspek yang sama antara ajaran tasawuf Wujudiyyah dengan konsep wahdatul wujud. Konsep tasawuf wahdatul wujud sendiri, menurut Canon Sell muncul sekitar abad 9-10 oleh alBayazid dari Bistam dan al-Junaid dari Baghdad. ${ }^{9}$ Pengikut al-Junaid yang terkenal adalah al-Hallaj yang dikenal dengan kalimatnya "ana al-haq", yang kemudian dianggap sesat dan dibunuh. Walaupun demikian, ajaran al-Hallaj tetap diikuti dan dipelajari. Diantara pengikutnya adalah Ibnu Arabi. Wahdatul Wujud merupakan teori tajalliat Ibnu Arabi yang berpusat pada ajaran tentang penciptaan alam dan manusia melalui penampakan 7 martabat. Dari Ibnu 'Arabi' inilah Hamzah Fansuri mempelajari konsep Wujudiyyah, yang kemudian diikuti oleh Syamsuddin AsSamatrani.

Sebagai Ulama' yang sangat mendukung penafsiran mistiko-filosofis wahdatul wujud, ajaran mereka misalnya menjelaskan bahwa alam raya dalam serangkaian emanasi-emanasi neo platonis dan menganggap emanasi sebagi bagian dari Tuhan itu sendiri ${ }^{11}$. Mereka juga mengajarkan bahwa Tuhan itu seolah-olah sama dengan mahluknya (ittihad) atau Tuhan dapat menitis dan menjelma kepada semua benda ciptaanNya. Jadi, bisa dikatakan bahwa dalam konsep wujudiyyah, semua benda adalah Tuhan, atau sebaliknya Tuhan adalah semua benda. ${ }^{12}$

Hal ini menjadi point kritik ArRaniri dalam konsep tasawufnya. Ada beberapa pendapat Ar-Raniri mengenai konsep wahdatul wujud tersebut, diantaranya adalah mengenai pendapat

\footnotetext{
9 Edwar Djamaris, Hamzah Fansuri dan ..., h. 6 .

10 Oman Faturrahma, Menyoal

Wahdatul Wujud...,h. 21.

${ }^{11}$ Azyumardi Azra, Jaringan Ulama

Timur, h. 200

12 Edwar Djamaris, Hamzah Fansuri dan ...,h. 6.
} 
bahwa 'wujud Tuhan dan wujud alam \& manusia adalah satu", Ar-Raniri berpendapat bahwa jika mahluk dan alam itu satu, maka semua hewan, tumbuhan dan hal-hal yang berwujud adalah Allah, dengan demikian apa yang dimakan, diminum, dibakar adalah Allah. Hal itu juga berarti bahwa segala perbuatan manusia, termasuk perbuatan tercela juga perbuatan Allah.

Dalam argument kedua, Ar-Raniri mengatakan bahwa jika memang benar bahwa Tuhan dan mahluk itu hakikatnya satu, maka manusia memiliki sifat-sifat Allah, dengan demikian manusia akan mengetahui dan dapat berbuat segala sesuatu, baik itu yang ada di langit dan di bumi. Dua argument ${ }^{13}$ tersebut cukup tepat dan masuk akal untuk menggugurkan ajaran wujudiyyah. Arraniri menjelaskan kedudukan Allah dan mahluk. Alam semesta merupakan ciptaan Allah dan Allah adalah penciptanya.

Selanjutnya, Ar-Raniri mealnjutkan diskusi ajaran wujudiyyah yang mengatakan bahwa "wujud Allah itu wujud mahkluk dan wujud mahkluk adalah wujud Allah",tidak terlepas dari empat kemungkinan:

1) Intiqal : wujud Allah berpindah kepada mahluk seperti seorang berpindah dari satu tempat ke tempat lain.

2) Ittihad : dua wujud menjadi satu, sepertinya menyatunya emas dengan tembaga

3) Hulul : wujud Allah masuk kedalam mahluk, seperti air masuk kedalam botol

4) Ittishal : wujud Allah berhubungan dengan mahluk, seperti manusia dengan anngotanya.

${ }^{13}$ Ibid, . 25-26
Empat kemungkinan tersebut jelas mustahil terjadi pada Allah dan tidak dapat diterima oleh akal. ${ }^{14}$

Hal kedua yang dikritik oleh ArRaniri adalah tentang ajaran wujudiyah yang menyatakan bahwa Syari'at berbeda dengan hakikat, sehingga perbedaan Tuhan dengan mahluk hanya dari segi Syari'atnya saja, bukan dari segi hakikatnya. Ar-Raniri dalam hal ini, mengambil pendapat beberapa 'Ulama' besar diantaranya adalah Abu Hafs Suhruardy yang menyatakan bahwa "setiap hakikat yang disanggah oleh syari'at, maka ia zindiq. Pendapat kedua diambil dari Abu Qasim al-Qusyairi bahwa "tiap-tiap hakikat yang tidak berkaitan dengan syari'at, maka ia tidak berhasil.

Adapun tentang apa ynag diucapkan Abu Mansur al-Hallaj, Abu Yazid al-Bustami dan lain sebagainya, seperti "ana al-haq", yang selalu dijadikan dalil keesaan hakikat Tuhan dengan mahkluk oleh kaum wujudiyyah, telah ditolak secara keras oleh Ar-Raniri dan dikatakan bahwa ucapan-ucapan semacam itu tidaklah menunjukkan wahdtul wujud, tetapi wahdatus syuhud. Kalimat-kalimat tersebut diucapkan pada saat tidak sadar, atau dalam keadaan fana. Dalam keadaan demikian, seseorang tidak memiliki sesuatu selain Tuhan, yang dalam tasawuf diditilahkan dengan " syathhiyah". Oleh karena itu, ucapanucapan tersebut tidak boleh dipegang dan ditafsirkan sebagaimana lahirnya. ${ }^{15}$

Dalam kitabnya Sirath al-Mustqim, ar-Raniri menekankan pentingnya syari'at dalam praktik tasawuf. Dalam kitabnya ini, Ar-Raniri menjelaskan tugas utama seorang muslim adalah beribadah sesuai dengan ajaran Nabi. Dia, secara rinci menjelaskan semua masalah fikih yang menyangkut tentang tata cara sholat, puasa, zakat, dan sebagaianya. Meskipun

${ }^{14}$ Ahmad Daudi, Syeikh Nuruddin Ar-

Raniri ..., h. 35.

15 Ibid,..., h. 38 . 
kelihatannya hanya terlihat seperti kitab fikih biasa, tetapi pentingnya kitab ini tidak dapat dikesampingkan, dikarenakan keadaan masyarakat saat itu yang menganut tasawuf eksesif dan spekulatif yang merajalela. ${ }^{16}$

$$
\text { Terkait dengan pendapat- }
$$
pendapar Ar-raniri, dapat dikatakan bahwa konsep tasawuf yang diajarkan oleh ar-Raniri adalah wahdatus Syuhud. ${ }^{17}$ Dalam tasawuf lebih dikenal dengan tauhid Syuhudi, yang secara sederhana berarti persepsi (syuhud) atas dzat tunggal dalam pengalaman mistiknya. Pengertian lain tentang konsep wahdatus Syuhud, yaitu melihat dzat tunggal atau menyatakan tiadanya sesuatu kecuali dzat tunggal. Jika melihat tentang aspek penekanan syari'at dalam konsep tasawufnya, Ar-raniri tentu mengambil konsep tasawuf yang diajarkan oleh alGhazali.

Ahmad Daudy, dalam disertasinya menjelaskan falsafah mistik Nuruddin Arraniri meliputi empat hal, yaitu: ${ }^{18}$

\section{Ontologi}

Bahwa yang ada hanya Allah saja. Allah adalah nama bagi suatu dzat yang mutlak dan tidak ada suatu apapun yang menyamainya. Disamping dzat, Allah mempunyai sifat-sifat atau nama-nama yang merepresentasiakan kesempurnaannya (asmaul husna). Dari segi wujud, sifat dan dzat Allaha dalah identic ('ain dzat). Sedangkan dari segi pengertian, keduanya berbeda. Allah berkendak melihat kesempurnaan diriNya, sehingga ia bertajalli melalui sifat dan asmaNya. Tajalli ini terjadi dalam tiga

218.

${ }^{16}$ Azyumardi Azra, Jaringan Ulama ...,h.

17 Rohliah, , Nuruddin Ar-Raniri dan Kontribusinya Pada Masa Sultan Iskandar Tsani, (Yogjakarta: Skripsi, UIN Sunan Kalijaga 2004), h. 54 .

${ }^{18}$ Ahmad Daudy, Allah dan Manusia Dalam Konsepsi Syeikh Nuruddin Ar-Raniry, (Rajawali, Jakarta: 1983), h. 81-183. martabat, yaitu : martabat wahidah (tajalli sifat), martabat wahidiyyah melahirkan a'yan tsabithah yang merupakan hakikat alam. Oleh karena sifat identic dengan dzat, maka hakikat alam itu (a'yan tsabithah), berada dalam dzat Allah. Pada martabat Ilahi ini, hakikat alam identic dengan Allah, yakni satu hakikat. Akan tetapi pada martabat selanjutnya, a'yan tsabithah yang berwatak potensial itu beralih kedalam wujud actual, sehingga lahirlah a'yan kharijiyyah, yakni alam empiris ini. Alam ini merupakan madhhar dari tajalli sifat dan asma Allah , sedangkan Allah tidak ada, atau tidak immanen dalam alam ini.

\section{Kosmologi}

Alam ini dijadikan Allah melalui tajalli. Alam ini terdiri dari alam tinggi dan alam bawah. Alam tinggi terdiri dari alam falak dan akal yang masing-masing terdiri dari Sembilan falak dan akal, hal ini sama seperti teori al-Farabi dan Ibn Shina. Alam bawah adalah alam anasir yang terdiri dari air, api, udara dan tanah. Alam tinggi memberi pengaruh alam bawah, sehingga lahirlah tumbuhan, hewan, jamaddat, dan manusia di bumi ini. Manusia adalah makhluk yang paling sempurna di bumi ini. Dengan lahirnya manusia, selesailah penciptaan alam ini seluruhnya.

\section{Manusia}

Manusia terdiri dari ruh (jiwa) dan jasad. Akan tetapi hakikat manusia adalah ruh, karena ruh kekal setelah terpisah dengan jasad. Jiwa adalah jauhar ruhani yang dijadikan Allah dari nur Muhammad dua ribu tahun sebelum jasad. Walaupun jasad merupakan alat bagi jiwa, keduanya saling memerlukan. Hubungan jiwa dengan jasad bersifat aksidental, sehingga ketika jasad hancur jiwa terpengaruh. Bila manusia mati, jiwanya akan kembali kea lam falak. Dan pada hari kiamat, akan dimintai pertanggung jawaban. 


\section{Agama}

Agama terdiri dari Iman, Islam, makrifat dan tauhid. Orang yang beragama tidak hanya harus beriman, artinya ia tidak sekedar percaya dengan kebenaran wahyu Allah dan melakukan kewajiban lahiriyah sesuai dengan yang diajarkan syari'at. Akan tetapi, setiap orang yang beriman juga harus memperoleh pengalaman ruhani melalui suluk dan tarekat. Makrifat atau pengalaman ruhani hanya dapat dialami saat seseorang dalam keadaan fana. Dengan makrifat tersebut, maka akan diperoleh keyakinan yang hakiki tentang makna tauhid yang sebenarnya, yaitu "tidak ada sesuatu kecuali Allah".

Dalam bidang tauhid, Ar-Raniri mengikuti Asy'ariyah dan maturidiyah sebagi pengikut paham ahlus sunnah wal jama'ah. Dalam bidang fikih, dia mendasarkan ajarannya pada kitab-kitab As-Syafi'i, Zakarya al-Anshari, dan Syamsuddi al-Ramli. Ar-Raniri juga mengarang kitab perbandingan agama dengan judul Tibyan fi Ma 'rifah al-Adyan. Penulisan kitab dirancang seperti kitab alMilal wa al-Nihal karya al-Syahrastani, akan tetapi pada sebagian isinya ia banyak mengutip dari Abu Syahura Alsalim dalam KItab al-tawhid.

Kitab ini berisi tentang agamaagama non skriptual dan skriptual, kemudian menjelaskan Islam dan 72 golongan yang keluar dari kelompok ahl al-Sunnah wa al-Jama'ah. dalam pembahasan ini, ia memasukkan pengikut wujudiyyah sebagai bagian dari kelompok sesat $^{19}$. Ar-raniri menyamakan ajaranajaran wujudiyah dengan argument filsuf Zoroaster dan kaum brahmaniah, kaum qadariyyah dan mu'tazilah. Pendapat penyesatan oleh ar-Raniri ini berujung pada pembunuhan para pengikut Hamzah Fnsuri dan Syamsuddin As-Samatrani

${ }^{19}$ Azyumardi Azra, Jaringan

Ulama...,h.226. yang tidak mau melepaskan keyakinan mereka. Juga pembakaran seluruh kitab karangan Hamzah Fansuri dan Syamsuddin As-Samatrani.

\section{Latar Belakang Pemikiran Nuruddin Ar-Raniri}

Karena Ar-Raniri banyak menulis tentang kalam dan tasawuf, jelas bahwa ia menganggap salah satu masalah dasar kalangan kaum kuslim-melayu Nusantara adalh tentang aqa'id (landasan keimanan). Karena itu, dengan intens ia berusaha menjelaskan anta lain hubungan hakikat Tuhan dengan alam raya dan manusia. Dia menjelaskan doktrin asy'ariyah tentang perbedaan manusia dengan mahluknya serta transendensi mutlah Tuhan dengan manusia. Dengan kepatuhan dan kesetiaannya terhadap ajaran asy'ariyah tidak sulit dipahami mengap ia bersikap begitu sengit terhadap ajaran dan pengikut Hamzah Fansuri dan Syamsiddin As-Samatrani.

Untuk menganalisis terbentuknya pola pemikiran Ar-Raniri, perlu dielaskan bagaimana prosesnya dalam mempelajari ilmu-ilmu keislaman. Guru Ar-Raniri yang paling terkenal adalah Abu Hafs Umar bin Abdullah Ba Syayban al-Tarimi alHadhrami, yang dikenal sebagai Umar alAydarus di wilayah Gujarat. ${ }^{20}$ Dari $\mathrm{Ba}$ Syayban, Ar-Raniri kemudian dimasukkan kedalam tarekat Rifa'iyah, sebuah tarekat Arab. Dalam usia yang relative muda, ArRaniri telah ditunjuk sebagai pemimpin tarekar Rifa'iyah, dan karenanya, aia bertanggung jawab untuk menyebarkan ajaran tarekat tersebut_dalam hal ini ke wilayah Aceh.

\section{Selain tarekat Rifa'iyah, Ar-Raniri} juga berafiliasi dengan tarekat Aydarusiyah dan Qadiriyah. Kaitannya dengan aydarusiyah, sangat menentukan dalam mengembangkan kecenderungan radikalnya. Aydarusiayh dengan akarakar arabiyahnya merupakan tarekat 
pembaharu di wilayah anak benua India. Dengan keras, Aydarusiyah menekankan keselarasan antara jalan mistis dan kepatuhan terhadap syari'at. Dari sini, sudah elas sekali darimana konsep tasawuf dan theology Ar-Raniri terbentuk. $^{21}$

Para ahli berusaha menjelaskan mengapa Ar-Raniri memanfaatkan kedudukannya sebagai Syaik al-Islam Kesultanan untuk mengkafirkan para pengikut wujudiyayah . Daudy misalnya, menyatakan kepribadian ar-Raniri yang tak kenal kompromi erat kaitannya dengan pengalaman masa lalunya ketika hidup di lingkungan Hindu yang penuh permusuhan di India. Konflik sosial yang berkepanjangan antar kelompok minoritas muslim dan mayoritas Hindu tidak menciptakan toleransi di dalam segmen-segmen keduan masyarakat tersebut, dan ar-Raniri adalah produk dari masyarakat semacam itu.

Konflik keagamaan Hindu-Islam di India memang terjadi sejak lama, terkait dengan kesamaan dengan kasus diaceh, dapat ditarik benang merah bahwa kasus ini berasal dari pertentangan antara kaum ortodoks dan heterodoks pada abad yang sama di India. Bermula dari kebijakan raja Moghul, Akbar untuk mendirikan sebuah eklestikisme keagamaan untuk menyatukan unsure-unsur terbaik dari Hindu dan Islam. Kemudian menciptaka agama baru yang disebut Din Ilahi. Kebijakan Akbar mengakibatkan ketegangan dan pertentangan Ulama; ortodoks yang menganggap toleransi keagamaan Akbar menyimpang dari ajaran Islam.

Paham ini semakin kuat pengaruhnya di India karena pengganti Akbar, yaitu Jahangir juga mendukung pendapat ini. Dalam konteks ini penting dikemukakan bahwa pada saat hampir bersamaan paham mistik Hamzah Fansuri

21 Ibid, ..., h. 217. dan Syamsuddin As-Samtrani sedang mencapai puncak keemasannya dibawah pimpinan Sultan Iskandar Muda.

Di India saat itu, adalah Ahmad Assirhindi yang dikenal sebagai Ulama' terdepan yang mewakili Ulama' ortodoks untuk menentang kebijakan tersebut. Pada umumnya, pandangan Ar-Raniri yang sejalan dengan Wahdatus Syuhud merupakan penge,banagn dari ide-ide AsSirkindi. Yang membuat dekat kedua tokoh sufi ini adalah kecenderungan mereka yang mencolok pada hukum syari'at daripada pengalaman ekstasis, penarikan garis yang tegas antara Tuhan dan alam, serta kritik tajam terhadap kecenderungan sifat-sifat bid'ah dalam praktik tasawuf

Pengaruh Din Ilahi berakhir pada masa kepemimpinan sultan selanjutnya, yaitu Shah Jahan yang menentang paham heterodoks. Dia menghancurkan kuil-kuil dan melarang membangun kuil baru. Pada masa yang hampir bersamaan pula,di Aceh pun terjadi perubahan politik dimana Ar-Raniri berhasil meyakinkan penguasa baru untuk menghukum para pengikut ajaran wujudiyyah. Dari sinilah, A.H. Johns ${ }^{22}$ mengambil kesimpulan bahwa kontroversi doktrin wujudiyah di Aceh merupakan konsekuensi dari perkembangan politik dan keagamaan di Moghul, India. Sedangkan Azra, ${ }^{23}$ mengutip pendapat Drewes berpendapt bahwa reaksi Ar-Raniri yang tak kenal kompromi tersebut merupakan semangat pembaruannya dalam masyarakat Aceh. Dengan kata lain, oposisi radikal ar-Raniri terhadap Hmazah Fansuri dan Syamsuddin AS-Samatran, dan para

22 Oman Faturarhman, Menyoal Wahdatul ...,h. 45. lihat juga Sangidu, Wahdatuk wujud: Polemik Pemikiran Sufistik Hamzah Fansuri dan Syamsuddin As-Samatrani dengan Nuruddin Ar-Raniri, (Yogyakarta: Gama Media, 2003), h. 23.

${ }^{23}$ Azyumardi Azra, Jaringan Ulama ...,h. 
pengikutnya merupakan reaksi ortodoksi dari praktik mistitisme yang menyimpang.

\section{Pengaruh Pemikiran Nurddin Ar- Raniri}

Hukuman mati terhadap pengikut wujudiyah meninggalkan dampak yang melekat lama dalam kehidupan Islam di Nusantara. Ini mendorong dilakukannya peninjauaan kembali atas pengkajian kembali atas konsep muslim dan kafir. Yang kemudian terdapat 'Ulama' yang mendamaikan perdebatan antara pengikut tasawuf wujudiyyah dengan para pengikut Ar-Raniri. Abdur Rauf AsSinkili adalah Ulama' pertama yang melakukannya. Yang kemudian diteruskan dan dikembangkan oleh murid-muridnya.

Melalui kitab-kitab yang dikarangnya, ajaran dan pemikiran Arraniri mempunyai pengaruh yang cukup kuat dalam masyarakat. Kebiasaan ArRaniri dalam mengutip pendapat para tokoh untuk mendukung argumennya meruapakn sarana pengenalan kaum Muslim Melayu terhadap pemikiran tokoh-tokoh tersebut. Ia adalah alim pertama yang mengambil inisiatif untuk mengarang kitab pegangan standar fikih yang berisi dasar-dasar tata cara beribadah. Dalam bidang politik, Ar-Raniri yang mempunyai kedudukan sebagai penasehat raja.

Melalui peranannya tersebut, ia menasehati Sultan dalam fungsinya sebagai penguasa dan khalifah di bumi. Dengan mengutip ayat al-Qur'an ia menjelaskan tugas-tugasnya kepada rakyat. Nasehat-nasehat yang ditulisnya dalam kitab Bustan as-Salatin ini kemudian menjadi contoh tatacara kepemimpinan bagi Sultan selanjutnya. Melalui berbagai peranannya selam di Aceh, ia cukup banyak mendapatkan simpati dan perhatian di masyarakat, sehingga namanya diabadikan menjadi nama perguruan tinggi agama di Banda Aceh, yaitu IAIN ar-Raniri.

\section{PENUTUP}

Kategori penyesatan ajaran wujudiyah oleh Nuruddin Ar-Raniri dipetakan dalam 3 alasan yaitu :

1. Wujudiyah identik dengan agama dan kepercayaan pra Islam seperti Nasrani, Majusi dan Brahmaniyah

2. Ajaran Wujudiyah sama dengan ajaran sekte-sekte sempalan dalam Islam pasca Rasulullah wafat, seperti Mu'tazilah dan Qadariyyah

3. Wujudiyyah merupakan pengamalan dari tarekat yang sesat dan menyimpang dari konsep Islam Sunni

Penentangan Ar-Raniri terhadap ajaran wujudiyyah ini terjadi secara alamiyah karena pada dasarnya ia adalah Ulama' dengan basic keilmuan sunni yang menganut paham Wahdatus Syuhud dalam konsep tasawufnya. Sementara dalam bidang keilmuan lainnya, seperti fikih jelas sekali bahwa ia merupakan Ulama' sunni yang setia terhadap ajaran Asy'ariyah. Hal ini tidak dapat dilepaskan dari pola pendidikan yang ia dapatkan dari gurunya. Selain itu, ia merupakan pemimpin dari tarekat Rifa'iyah dan Aydarusiyah, yang sangat menekankan keselaran praktik syari'at dalam pengalaman mistis. Sedangkan sikap non kompromisnya terhadap para pengikut wujudiyah dikaitkan dengan kehidupan masa lalunya di India yang hidup dalam konflik berkepanjangan antara Hindu dan Islam yang tidak toleran.

Terlepas dari pernyataan penyimpangan dan pensesatan Ar-Raniri terhadap doktrin wujudiyah tersebut, pengkafiran apalagi pembunuhan pada setiap pengikutnya tetap tidak dapat dibenarkan. Dalam konteks tasawuf falsafi, tentu saja terdapat beberapa hal yang rumit dan sulit dipahami. Dan bisa saja, doktrin tersebut hanya dipahami dalam konteks harfiahnya saja. Pembakaran atas kitab-kitab karangan 
Hamzah Fansuri dan Syamsuddin AsSamatrani juga merugikan khazanah keilmuan Islam di Nusantara.

Walaupun demikian, tidak dapat dipungkiri bahwa Ar-Raniri mempunyai pengaruh yang besar dalam penyebaran keilmuan Islam di Nusantara. Ia mendorong beberapa Ulama' selanjutnya untuk mengkaji ulang ajarann-ajarannya, yang kemudian menghasilkan pemikiranpemikiran baru lagi. Kitab-kitab Ar-Raniri juga cukup banyak yang dapat dikaji dan digunkana oleh masyarakat Aceh pada masa itu.

\section{DAFTAR PUSTAKA}

Abdillah, Ali Muhammad, Tasawuf Kontemporer Nusantara, Jakarta: Ina Publikatama, 2011.

Azra, Azyumardi. Jaringan Ulama Timur Tengah dan kepulauan Nusantara Abad XVII \& XVIII, Jakarta: Kencana, 2007.

Daudy, Ahmad. Allah dan Manusia dalam Konsepsi Syaihk Nuruddin Ar-Raniry, Jakarta: Rajawali, 1983.

Syaihk Nuruddin Ar-Raniry:

Sejarah, Karya dan Sanggahan terhadap Wujudiyyah di Aceh, Jakarta: Bulan Bintang, 1978.

Djamaris, Edwar, Hamzah Fansuri dan Nuruddi Ar-Raniri, Jakarta: Proyek Pengembangan Media Kebudayaan Direktorat Jenderal Kebudayaan Departement Pendidikan Dan Kebudayaan, 1995.

Fathurrahman, Oman. Menyoal

Wahdatul Wujud: kasus Abdurrahman Singkel di Aceh Abad 17, Jakarta: Mizan, 1999.

Rohliah,Nuruddin Ar-Raniri dan Kontribusinya Pada Masa Sultan Iskandar Tsani, Yogjakarta: Skripsi,
UIN Sunan Kalijaga, 2004.

Sangidu, Wahdatul wujud: Polemik Pemikiran Sufistik Hamzah Fansuri dan Syamsuddin As-Samatrani dengan Nuruddin Ar-Raniri, Yogyakarta: Gama Media 2003. 